\title{
Asymptomatic Cholecystocolic Fistula Diagnosed Accurately before Surgery
}

\author{
Nam Yeol Cho', Si Eun Hwang ${ }^{2}$ \\ Departments of ${ }^{1}$ Gastroenterology, ${ }^{2}$ Surgery, Daejeon Sun Hospital, Daejeon, Korea
}

Cholecystocolic fistula (CCF) is a rare and late complication of gallbladder disease. The cause of CCF is known to be peptic ulcer, gallbladder disease, malignant tumor, trauma, and postoperative complications. The proper treatment method is to perform cholecystectomy and to identify and alleviate the CCF. However, cholecystectomy is not always possible owing to technical difficulties and disease severity. CCF is difficult to diagnose preoperatively, and CCF operation without an accurate preoperative diagnosis can lead to a more complicated surgery and cause surgeons to face more difficult situations or to endanger patients' lives. We report a case of asymptomatic CCF successfully treated with laparoscopic surgery after accurate diagnosis before surgery.

Korean J Pancreas Biliary Tract 2019;24(2):84-88

Keywords: Cholecystocolic fistula, Laparoscopic surgery, Gallbladder stone

\author{
Received Oct. 11, 2018 \\ Revised Dec. 3, 2018 \\ Accepted Dec. 28, 2018 \\ Corresponding author : Si Eun Hwang \\ Department Surgery, Daejeon Sun Hospital, 29 \\ Mokjung-ro, Jung-gu, Daejeon 34811, Korea \\ Tel. +82-42-220-8575 Fax. +82-42-220-8169 \\ E-mail; sursehwang@gmail.com \\ ORCID: https://orcid.org/0000-0001-5628-2420
}

This is an Open Access article distributed under the terms of the Creative Commons Attribution Non-Commercial License (http:// creativecommons.org/licenses/by-nc/3.0/) which permits unrestricted non-commercial use, distribution, and reproduction in any medium, provided the original work is properly cited.

Copyright $\odot 2019$ by The Korean Journal of Pancreas and Biliary Tract

\section{INTRODUCTION}

Cholecystoenteric fistula is a late complication of gallbladder disease due to repeated inflammation and adhesive formation between the gallbladder and the bowel. ${ }^{1-3}$ Fistula into the duodenum (75\%) is the most common, followed by those into the colon (10-20\%), stomach, jejunum, and abdominal wall. ${ }^{2-4}$

Cholecystocolic fistula (CCF) is a rare disease with no specific symptoms. ${ }^{1}$ Therefore, CCF is reported as rare as $0.06 \%$ to $0.14 \%$ during cholecystectomy. ${ }^{4,5}$ For this reason, if CCF such as pneumobilia is suspected in a patient with multiple gallbladder stones, a thorough radiological evaluation for definite diagnosis is required before treatment. We herein report a case of an incidentally discovered asymptomatic CCF that was preoperatively diagnosed and successfully managed using laparoscopic surgery.

\section{CASE}

A 56-year-old woman visited Daejeon Sun Hospital with indigestion that occurred 3 days before admission. At the 
time of admission, her vital signs were normal and physical examination revealed mild discomfort in the epigastric area, but no rebound tenderness or abdominal stiffness. Blood chemistry analysis revealed the following values: total bilirubin, $2.4 \mathrm{mg} / \mathrm{dL}$; direct bilirubin, $0.9 \mathrm{mg} / \mathrm{dL}$; and aspartate aminotransferase/alanine aminotransferase, 194/103 IU/L. Hepatitis B and C virus markers were negative. A plain radiography of the abdomen revealed no remarkable findings. Abdominal computed tomography (CT) was first performed to determine diseases such as cholecystitis and cholangitis based on abnormal liver function test results. Abdominal CT revealed the presence of cholelithiasis, unexplained multiple air bubbles in the gallbladder, and diffuse bile duct dilatation (Fig. 1A, B). To confirm the cause of the multiple air bubbles in the gallbladder and diffuse bile duct dilatation in correlation to the abdominal CT findings, abdominal ultrasonography was additionally performed. On examination, CCF was suspected owing to the incidental observation of lesions that appeared in the tract between the colon and the gallbladder, although it was not a typical abdominal ultrasonography finding, like the wall-echo shadow triad or double-arch shadow sign (Fig. 1C). Magnetic resonance cholangiopancreatography (MRCP) was subsequently
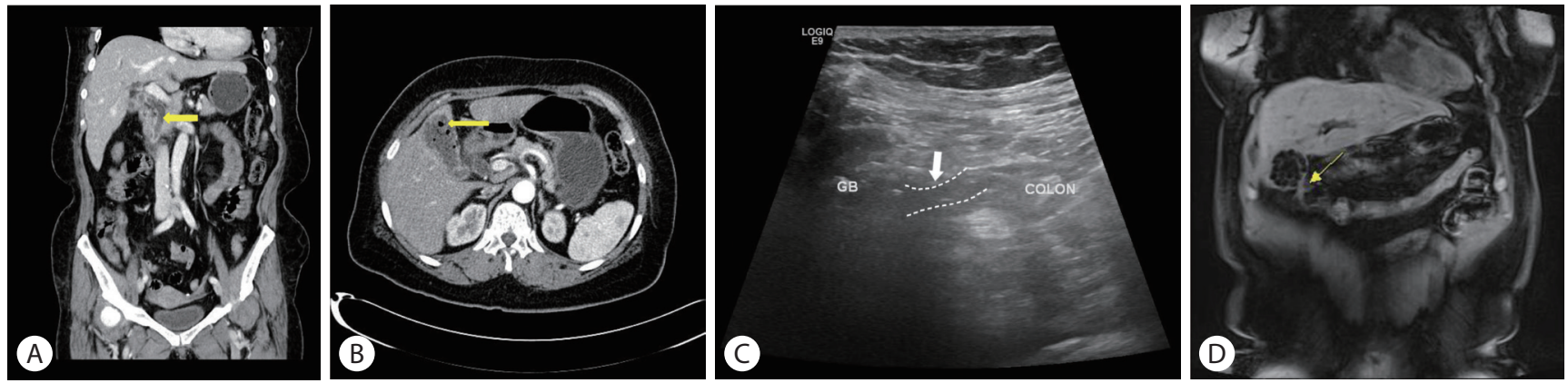

Fig. 1. (A) Abdominal CT (arterial phase) image demonstrating multiple air bubbles in the gallbladder (yellow arrow). (B) Abdominal CT (coronal view) image demonstrating the finding of common bile duct dilatation (yellow arrow). (C) Abdominal ultrasonography image showing the tract between the gallbladder and the colon (white dotted lines, white arrow). (D) Magnetic resonance image (coronal T1W image) showing an adhesive formation between the proximal transverse colon and the gallbladder, and high signal intensity lesions of the tract (yellow arrow). CT, computed tomography.

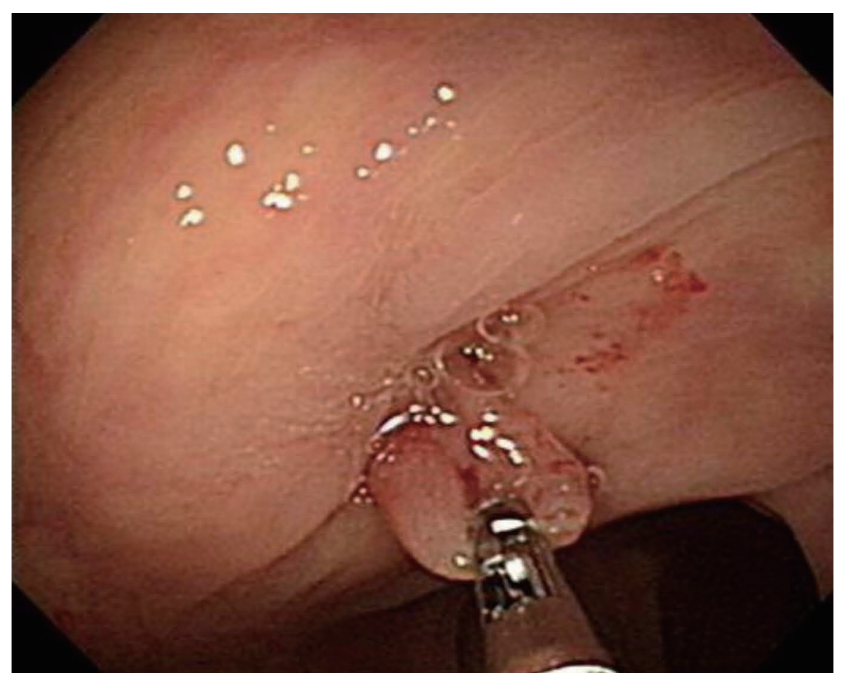

Fig. 2. The colonoscopy image on the left shows an inflammatory polyp at the transversal colon. The colonoscopy image after the irrigation shows an enteric fistula with a leaking air bubble.

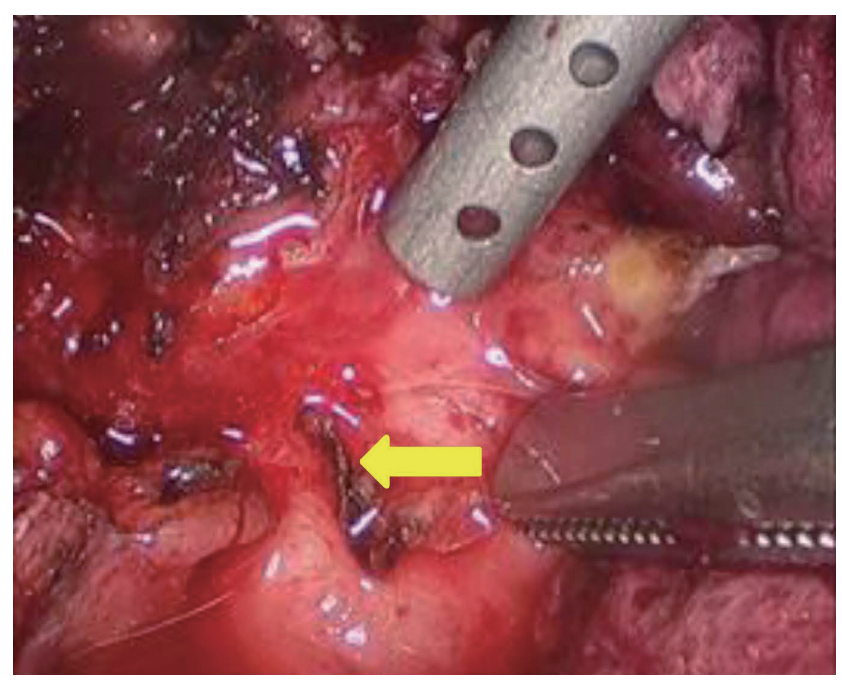

Fig. 3. Laparoscopic surgical findings showing the fistula between the gallbladder and the colon (yellow arrow). 


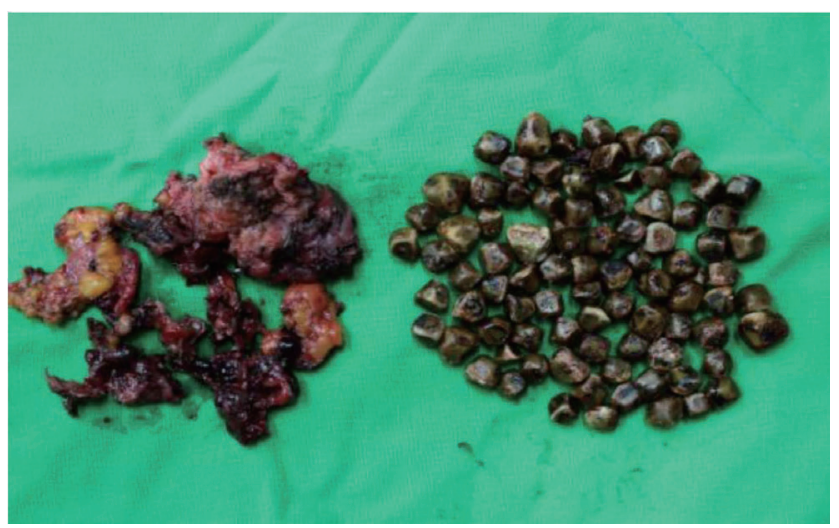

Fig. 4. Necrotic gallbladder tissue and multiple gallbladder stones after the operation.

performed and revealed common bile duct stones and a loss of contour of the gallbladder fundus. We also found that gallbladder fundus and intestinal lumen adjacent to it appeared as a tubular structure with high signal intensity. These findings led us to the diagnosis of CCF (Fig. 1D). We performed endoscopic retrograde cholangiopancreatography (ERCP) to remove the common bile duct stones, which were evident in the imaging findings. CCF was additionally diagnosed as a lumen with a yellow pus discharge in the proximal transverse colon on colonoscopy. We confirmed that the discharge was constantly flowing when washed with water (Fig. 2). An endoscopic biopsy showed that the protruding lesion of the fistula was an inflammatory lesion. Laparoscopic exploration revealed that the gallbladder had severe adhesions to the omentum, duodenum, and colon. The gallbladder wall was so thin that even careful dissection would cause a severe tear. Several gallbladder stones were present in the gallbladder, and the stones were embedded in the entire gallbladder lumen like a honeycomb. The adhesion around the gallbladder was carefully removed, and the site of the CCF was confirmed (Fig. 3). Laparoscopic endoloop and hem-o-lok were used to ligate the fistula. The multiple gallstones embedded in the gallbladder were removed one by one using laparoscopic forceps. By using MRCP, abdominal CT, and colonoscopy, we confirmed no ischemic change, hidden malignancy, and lymph node enlargement in the normal mucosa adjacent to the fistula. Therefore, we

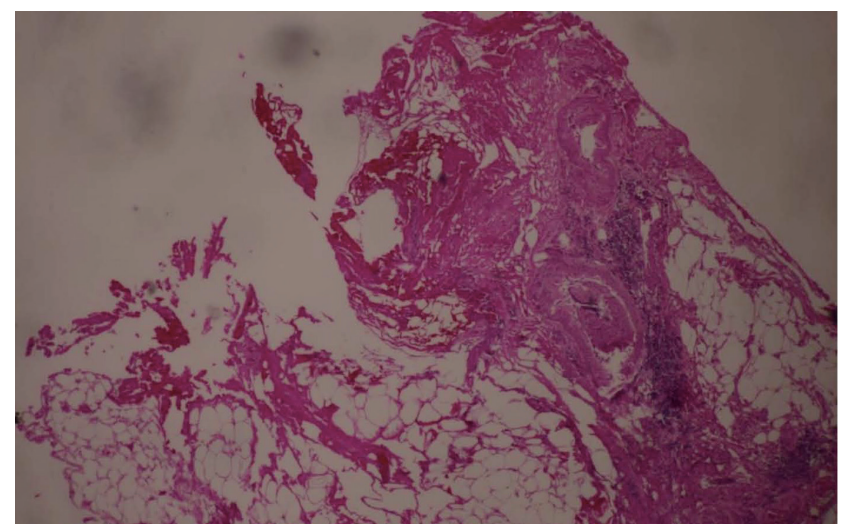

Fig. 5. Histological finding also confirmed it as fistula (hematoxylineosin, original magnification $\times 40$ ).

planned a laparoscopic operation, and successfully performed laparoscopic cholecystectomy and fistulectomy. After the cholecystectomy, diet was started on the third day after the operation, and the patient was discharged on the fifth day without postoperative complications. The resected specimens showed acute and chronic cholecystitis, empyema (Fig. 4) and the fistula tract on histopathological examination (Fig. 5).

\section{DISCUSSION}

Cholecystocolic fistula (CCF) is a rare disease. ${ }^{1-3} \mathrm{CCF}$ is due to repeated inflammation and adhesive formation between the gallbladder and the colon. ${ }^{2,4}$ The etiology of CCFs is diverse, including malignant tumors, trauma, postoperative complications, diverticular disease, and most frequently, complicated biliary lithiasis. ${ }^{3,7,8}$

A sequence of events occurs in acute and chronic inflammation of many different causes, resulting in the inflammation of the adjacent colonic serosal surface and adhesion to the gallbladder. ${ }^{1,3,6}$ The ischemic area in the wall of the gallbladder or colon becomes gangrenous, and the increased pressure within results in its contents penetrating its own necrotic wall at first and then the wall of the adjacent organs, forming a CCF. ${ }^{9,10}$

A spontaneous CCF comprises $10-20 \%$ of all biliary enteric fistulas. ${ }^{3,11,12}$ Clinical symptoms of CCF include 
chronic diarrhea, abdominal pain, jaundice, fever, nausea, vomiting, steatorrhea, weight loss, hemorrhagic diathesis, and bowel obstruction. ${ }^{2-4}$

Various diagnostic methods can be used, such as abdominal ultrasonography, CT, magnetic resonance imaging, ERCP, and barium angiography. ${ }^{7.8}$ However, in most cases, preoperative diagnosis is difficult because of nonspecific clinical symptoms, which are found incidentally during laparoscopic surgery and is a major cause of open conversion. ${ }^{8,9,12}$ Occasionally, CCF operation without an accurate preoperative diagnosis can lead to a more complicated surgery and can cause surgeons to face more-difficult situations or endanger patients' lives. ${ }^{5,13}$

The proper method of treatment is to perform cholecystectomy and to identify and alleviate the CCF. ${ }^{4,5}$ However, cholecystectomy is not always possible owing to technical difficulties and disease severity. ${ }^{5}$

The specificity of this case is that the patient had a simple symptom of dyspepsia, but the postoperative histological findings showed severe inflammation such as gallbladder empyema and CCF. Generally, obstruction of the cystic duct causes the symptoms of chronic calculus cholecystitis. However, in this patient, bile discharge through the CCF resolved the obstruction of the cystic duct and thus caused no symptoms. In our case, repeated chronic calculus cholecystitis resulted in increased pressure in the gallbladder, and ischemia and necrosis of the gallbladder wall.

If CCF is diagnosed preoperatively, early elective cholecystectomy and primary repair of the fistulous tract are recommended to avoid serious complications. Like our case, we diagnosed CCF before surgery and performed preoperative special care, including bowel preparation, colonoscopic evaluation, and biopsy and fistula site position detection. We report a case of asymptomatic CCF with severe inflammation that was successfully treated with laparoscopic surgery with accurate diagnosis before surgery.

\section{요 약}

담낭-대장 누공은 매우 드문 만성 담낭질환 중 하나이다. 그 원인으로는 소화성궤양, 담낭질환, 악성종양, 외상, 수술 후 합병증 등이 있다. 적절한 치료는 담낭절제술을 시행하고 담낭-대장 누공을 확인하여 해소시켜주는 것이다. 하지만, 본 질환의 중증도나 진단적 어려움 때문에 항상 담낭절제술이 가능한 것은 아니다. 담낭-대장 누공은 수술 전에 진단하기는 매우 어렵고, 정확한 진단 없이 수술을 진행하게 되면 좀 더 복잡한 수술이 될 수 있어 환자들에게는 심각한 생명의 위험을 줄 수 있다. 따라서 우리는 무증상의 담낭-대장 누공을 수술 전에 정확히 진단하고 성공적으로 복강경 수술로 치료한 증례를 보고하는 바이다.

국문 색인: 담낭-대장 누공, 복강경 수술, 담석

\section{Conflicts of Interest}

The authors have no conflicts to disclose.

\section{REFERENCES}

1. Gora N, Singh A, Jain S, Parihar US, Bhutra S. Spontaneous cholecystocolic fistula: case report. J Clin Diagn Res 2014;8:164-165.

2. Salemis NS, Georgoulis E, Tsohataridis E. Cholecystocolic fistula: an unusual presentation and review of literature. Trop Gastroenterol 2009;30:152-153.

3. Wang WK, Yeh CN, Jan YY. Successful laparoscopic management for cholecystoenteric fistula. World J Gastroenterol 2006;12:772-775.

4. Conde LM, Tavares PM, Quintes JL, Chermont RQ, Perez MC. Laparoscopic management of cholecystocolic fistula. Arq Bras Cir Dig 2014;27:285-287.

5. Dwivedi AN, Kumar S, Rana S, Maurya B. Transmural invasion of hepatic flexure of colon causing cholecystocolic fistula by aggressive gallbladder carcinoma. World J Surg Oncol 2013;11:86.

6. Hussien M, Gardiner K. Omental and extraperitoneal abscesses complicating cholecystocolic fistula. HPB (Oxford) 2003;5;194-196.

7. Velayos Jiménez B, Gonzalo Molina MA, Carbonero Díaz P, Díaz Gutiérrez F, Gracia Madrid A, Hernández Hernández JM. Cholecystocolic fistula demonstrated by barium enema: an uncommon cause of chronic diarrhoea. Rev Esp Enferm Dig 2003;95:811-812, 809-810.

8. Pua U, Merkle EM. Case report. Spontaneous cholecystocolic fistula and locoregional liver tumour ablation: a cautionary tale. Br J Radiol 2011;84:e243-e245. 
9. Correia MF, Amonkar DP, Nayak SV, Menezes JL. Cholecystocolic fistula: a diagnostic enigma. Saudi J Gastroenterol 2009;15:42-44.

10. Glenn F, Reed C, Grafe WR. Biliary enteric fistula. Surg Gynecol Obstet 1981;153:527-531.

11. Angrisani L, Corcione F, Tartaglia A, et al. Cholecystoenteric fistula (CF) is not a contraindication for laparoscopic surgery. Surg Endosc
2001;15:1038-1041.

12. Balent E, Plackett TP, Lin-Hurtubise K. Cholecystocolonic fistula. Hawaii J Med Public Health 2012;71:155-157

13. Toll EC, Kelly MD. Successful management of cholecystocolic fistula by endoscopic retrograde cholangiopancreatography: a report of two cases. Hong Kong Med J 2010;16:406-408. 